\title{
From the Russian food import ban to free trade from Lisbon to Vladivostok - will farmers benefit?
}

\author{
Martin Banse \\ Institute of Market Analysis, Thünen Institute \\ Germany \\ martin.banse@thuenen.de
}

\section{Ivan Duric}

Department of Agricultural Markets, Leibniz Institute of Agricultural

Development in Transition Economies (LAMO)

Germany

duri@iamo.de

\section{Linde Götz}

Department of Agricultural Markets, Leibniz Institute of Agricultural

Development in Transition Economies (LAMO)

Germany

goetz@iamo.de

\section{Verena Laquai}

Institute of Market Analysis, Thünen Institute

Germany

verena.laquai@thuenen.de

Abstract. With the implementation of the Russian import ban as a countermeasure to the EU sanctions in the context of the Ukrainian crisis, trade relations between the EU and Russia reached their lowest level in 2014. In this paper, we model several trade policy scenarios and assess their effects on domestic agricultural production and trade in Russia, the EU and Germany for the 2020-30 period. The results of the applied general equilibrium MAGNET model suggest that the removal of the Russian food import ban will affect Russian agricultural production to a limited extent only, while there will be no effect on the EU. In contrast, depending on how competitive Russian farmers' become, the creation of a large free trade area from Lisbon to Vladivostok would generally benefit farmers in the EU more than farmers in Russia.

Keywords: EU, Eurasian Economic Union, free trade area, import ban, MAGNET, Russia.

JEL Classification: D58, F13, F17, Q17, Q18 


\section{INTRODUCTION}

Trade relations between Russia and the European Union (EU) have been tense for years. The trade relationship between the two regions reached its lowest point in in August 2014, when Russia introduced an import ban on a wide range of agricultural products from the EU, the United States of America (USA), Norway, Canada, and Australia. The food import ban was established by the Russian government as a countersanction against the sanctions put in place by western countries against Russia because of the Ukrainian crisis. Set to last until the end of 2019, the food import ban was extended for the fourth time in July 2018.

Before 2014, Russia was the second largest market for EU agri-food exports, reaching almost 16 billion USD annually. The EU exports of pork and beef to Russia reached 1.2 billion USD in the years leading up to the crisis, accounting for $20 \%$ and $40 \%$ of total Russian pork and beef imports, respectively (UN COMTRADE, 2017). EU dairy exports to Russia were significant as well, reaching almost one-quarter of total EU dairy exports. Among the EU Member States, Germany was one of the countries that could potentially lose the most from the Russian trade policy, as it accounted for $14 \%$ of the total EU agri-food exports to Russia (in value terms in 2013). This number was higher for pork exports specifically, with Germany having a leading position, accounting for $24 \%$ of total EU pork exports to Russia, as well as for cheese exports, with Germany accounting for $14 \%$ of total cheese exports and ranking second right behind the Netherlands (UN COMTRADE, 2017).

Alongside disruptions in trade relations between the EU and Russia, an initiative to create a common economic area ranging from Lisbon to Vladivostok is gaining in importance. The Lisbon-Vladivostok free trade area could be created by liberalising trade between the EU and the Eurasian Economic Union (EAEU) ${ }^{1}$, comprising 32 countries with more than 800 million people and generating an additional economic value of about 20,000 billion USD (Felbermayr et al., 2016).

The initial idea of the Lisbon-Vladivostok free-trade area dates back to one of Vladimir Putin's, the current president of Russia, official visits to Germany in 2001. Later on, in 2010, during an interview with the German media (Süddeutsche Zeitung, 2010), Vladimir Putin spoke publicly about his vision of an economic community from Lisbon to Vladivostok that would lead to a common continental market. Recently, the idea of a free trade area with the EAEU has also been supported by high-level EU representatives, including the EU Commission president Jean-Claude Juncker since 2015 and especially the German chancellor Angela Merkel since 2015 (EastContact, 2017). A working group for a Common Economic Space from Lisbon to Vladivostok was founded in 2015 in Germany by decision makers from business, politics and research from different countries in Europe and Eurasia. Documented in a memorandum, the vision of the movement is to combine "Western engineering knowledge and experience with the outstanding IT skills in the East, thus enhancing the 'fourth industrial revolution' in the EU, EAEU and in the countries between (Freytag 2018, p. 50)". By the end of 2018, this movement was supported by about 15 companies and 10 business associations (Freytag, 2018).

For the movement for a Common Economic Space from Lisbon to Vladivostok to further grow, it is essential that governments and governmental institutions of the EU and EAEU, and especially Russia, engage in this process. However, current geo-political developments do not indicate that the vision of a Common Economic Space, and especially free trade between the EU and Russia, will be achieved in the near future. The core factors causing the present problems in economic and political relations between the

\footnotetext{
${ }^{1}$ The Eurasian Economic Union was established in 2015 by Belarus, Kazakhstan and Russia and later joined by Armenia and Kyrgyzstan. It is a free trade area comprised of 183 million people.
} 
East and West are far from being resolved. These problems include further NATO and EU enlargement towards the Black Sea (considered a major threat to Russia), the creation of an EAEU Eurasian alliance (considered a threat to the EU and USA), the Russian annexation of Crimea (resulting in economic sanctions imposed by the EU and USA), and many other economic issues (e.g. the supply of natural gas from Russia to the Ukraine and the EU).

Russia's food import ban should also be viewed as an element of the country's agricultural import substitution policy aimed at further developing its food sector by mobilising its unutilised agricultural production potential. By imposing import taxes, non-tariff barriers and even import bans, the import of agricultural and food products is evidently reduced. Concurrently, additional incentives for investments in the domestic agricultural and food sector have been created in order to substitute imports with domestically produced products. This has been achieved by providing comprehensive financial support within several agricultural subsidisation programs (Prikhodko \& Davleyev, 2014). Ultimately, this policy should not only decrease Russia's food import dependency and increase food self-sufficiency, but also move Russia towards becoming a large agricultural and food exporting country on world markets (Götz \& Djuric, 2016).

In light of the political segregation of the two economic regions through economic sanctions from both sides, the spreading of the idea of a Lisbon-Vladivostok free trade area, and an agricultural policy framework aiming to make Russia a large agri-food exporting country, this paper develops different scenarios of future Russian agricultural production and trade, especially with the EU. We address the research question of how Russia's domestic agricultural sector will develop from 2020 to 2030, assuming the continuation of the food import ban and high domestic support for Russian agriculture. Furthermore, we also aim to answer the question of how agricultural production and trade will develop if the food import ban is removed. We also consider the effects of a rather hypothetical scenario of an EU-EAEU free trade area on agricultural sectors.

This paper adds to the literature assessing the economic effects of the Russian food import ban on the food sectors of the EU and Russia. However, this study is unique in that it simulates the effects of a LisbonVladivostock free trade area on the agri-food sector in the EU and Russia using a disaggregated, productspecific perspective. This scenario has only been investigated before by Felbermayr (2016) on an aggregated level for the agri-food sector as a whole.

This paper is structured as follows: Section 2 provides an overview of EU-Russia trade relations before and after the Russian food import ban. Section 3 presents a literature review on the impact of the Russian food import ban on both Russian and EU markets. Section 4 describes the methodology and data used for the analysis based on the MAGNET modelling framework, while section 5 gives empirical modelling results. Conclusions are drawn in section 6.

\section{TRADE RELATIONS AND POLICY DEVELOPMENTS BETWEEN THE EU AND RUSSIA}

Before 2014, Russia imported about 50\% of its annual food consumption (worth about 43 billion USD), with mainly meat, fruits and dairy products accounting for $41 \%$ of total Russian food imports (value of 17.5 billion USD). About $68 \%$ of total meat imported was bovine and swine meat (value of 4.5 billion USD); $60 \%$ of the fruit imported was citrus fruits, apples and bananas ( 3.8 billion USD); and $50 \%$ of all dairy imports were cheese (2 billion USD) (UN COMTRADE, 2017).

The EU was one of Russia's largest trading partners, accounting for $37 \%$ of the total agri-food imports to Russia in 2013. More than $50 \%$ of the total imports from the EU to Russia were meat (representing 32\% of Russia's total meat imports), beverages (61\% of Russia's total beverage imports), dairy products (44\%), fruits $(26 \%)$ and vegetables (35\%) (UN COMTRADE, 2017). Among the EU Member States, Germany 
was one of Russia's main trading partners, especially for the product groups with the largest share of EU exports to Russia, such as meat and dairy. Regarding meat specifically, German exports to Russia accounted for 21\% of total EU exports with a generated value of 443 million USD in 2013 (UN COMTRADE, 2017). Out of all meat sub-categories, Germany mainly exported pork to Russia, equivalent to 24\% of total EU exports to Russia, with a generated value of 306 million USD. Concerning dairy products, Germany predominantly exported different types of cheese, reaching a trade value of 186 million USD in 2013 and accounting for $14 \%$ of the total EU cheese exports to Russia.

Trade relations between the EU and Russia were based on a Partnership and Cooperation Agreement created in 1997. In order to improve trade relations with Eastern European countries, the EU developed the European Neighbourhood Policy (ENP) in 2004. Within this framework, the EU initiated the Eastern Partnership Program (i.e. strong bilateral co-operation) with Armenia, Azerbaijan, Belarus, Georgia, Moldova and Ukraine in 2009. However, the ENP did not include Russia. Furthermore, the EU negotiated Deep and Comprehensive Free Trade Agreements (DCFTA) with Georgia, Moldova and the Ukraine on the free movement not only of goods, but also services, capital and people. Nevertheless, a DCFTA was not concluded with Russia. Negotiations on a new EU-Russia trade agreement were initiated in 2008 but stopped in 2010 when Russia, Kazakhstan and Belarus formed a customs union (van Berkum, 2014). The WTO accession of Russia in August 2012 brought about comprehensive import tariff reductions for food products. For example, the tariff on pork imported from the EU was reduced from 40\% to 5\% (within the quota tariff).

By 2014, the trading relationship between Russia and the EU had become quite tense. In that year, Russia banned all imports of pig meat originating from the EU due to several cases of the African swine fever arising in Poland and Lithuania in January 2014. At the same time, the Russian government banned the imports of dairy products originating from the Netherlands and Germany because of sanitary reasons. Third, in mid-2014, all imports of fruits and vegetables from Poland were banned. Finally, Russia introduced an import ban on certain agricultural products originating from the EU, USA, Norway, Canada and Australia in August 2014. The import ban was mainly focused on bovine and pig meats, processed meats, poultry, fish and other seafood, different dairy products, vegetables and fruits. Thus, the food import ban was applied to all of the products for which the EU had a large share in total Russian imports. As Russia is not selfsufficient in the banned products, meaning the country greatly depends on imports, concerns were raised about the effects of the ban on the domestic market in Russia, as well as on the markets of its main trading partners (Yatsenko et al., 2017).

Russia's food import ban has been extended many times since 2014. The latest extension of the ban was made on July 12, 2018, when the Russian government announced that the ban will be valid until the end of 2019. In parallel with the food import ban, the Russian government has been heavily supporting the development of the agricultural sector (Götz \& Djuric, 2016; Prikhodko \& Davleyev, 2014). During the four years under the food import ban, protected agricultural sectors started reaching self-sufficiency targets set by the Russian government. As an example, the pork sector had already reached $86 \%$ of the selfsufficiency target in 2016 (Götz \& Jaghdani, 2017). In contrast, developments in the dairy sector were much less active. Despite a significant increase in the self-sufficiency of cheese production (about 20\%), quality deficiencies are significant and consumers prefer imported cheese over domestically produced cheese (Tleubayev et al., 2018). 


\section{LITERATURE REVIEW}

In light of the tense political and economic relations between the EU and Russia, most of the existing literature assesses the impact of the Western sanctions towards Russia on one side, and the impact of the Russian food import ban, as a countermeasure to the sanctions, on the other side.

To assess the economic impact of the sanctions imposed towards Russia and the Russian food import ban, it should also be pointed out that the depreciation of the Russian Rouble and the economic downturn in Russia may have similar effects on the Russian economy (Tyll et al., 2018; Nelson, 2017; Aalto \& Forsberg, 2016). In addition, economic sanctions towards Russia might have negative effects on Russia's main trading partners due to spillover of the low economic growth (long-term effects) or countermeasures implemented by Russia (i.e. the food import ban of 2014), which might cause problems for partner countries as they would need to seek out alternative markets (mainly short-run effects).

Most of the existing literature on the 2014 sanctions investigates the impact of the Russian food import ban on trade and domestic price developments in Russia and its main trading partners, such as the EU (e.g. European Parliament, 2017). Following the Russian food import ban of 2014, as the primary agricultural trading partner of Russia, the EU lost its market share abruptly. The short-term negative effects of the Russian food import ban of agri-food exports from the EU has been analysed by several studies. Van Acoleyen (2015), for example, found that the Russian import ban had a negative effect on both banned and non-banned products' exports from the EU, with the highest impact found for perishable agricultural products. Judit and Nikulin (2017) also found a negative impact on European agri-food trade, especially for the dairy and meat sectors.

The EU Member States were not equally affected by the Russian food import ban. Depending on the volume of their agri-food exports to Russia prior to 2014, some Member States paid a higher toll than others. According to Veebel and Markus (2018) and Mauricas (2015), the Baltic States (Lithuania, Estonia and Latvia) faced reduced economic growth of about $0.6 \%$ of GDP as a direct consequence of the Russian sanctions. The strongest effect on EU agricultural exports was recorded for fruits and vegetables, where prices dropped significantly in the short run (Boulanger et al., 2016). This was especially the case for Poland, Lithuania, Greece and Belgium. The dairy sectors of Finland, Lithuania and Hungary were also negatively affected by the Russian food import ban (Mo, 2016; Sagi \& Nikulin, 2017). Giumelli (2017) found that Germany and Italy recorded the highest losses (in value terms) from the Russian countermeasures; the value of their total exports to Russia was reduced by 8.5 and 2.4 billion EUR, respectively. Nevertheless, Fedoseeva (2016) argues that the losses of German agri-food exporters were not that severe when compared with previous trade disruptions of German milk and meat exports to Russia, specifically in 2013 when Russia banned imports of specific products originating from the EU because of sanitary reasons. Furthermore, Fedoseeva points out that, for the German dairy market specifically, the Russian food import ban had a very low price-dampening effect on the end-consumer prices (0.35-0.75 EUR per $100 \mathrm{~kg}$ ). In contrast, a study conducted by the German Federal Ministry of food and agriculture (BMEL, 2014) indicates that there were hardly any price-damping effects of the Russian food import ban on the end-consumer prices of milk in Germany. As Russia had already banned meat imports from Germany in 2012, the same result was found for the German meat market.

Overall, the impact of the Russian food import ban mainly had a short-run negative effect for certain EU Member States (Boulanger et al., 2016; Dillen, 2015; Kutlina-Dimitrova, 2015). In particular, exports from the EU countries almost recovered within a year, and they even started recording an increase. This was mainly possible due to quick switches to other markets, particularly in East Asia, and by restructuring domestic production, as was the case in Lithuania, where previously exported raw milk to Russia was 
processed into butter and skim milk and sold mainly on domestic and neighbouring EU markets (Vitunskiene \& Serva, 2017; Kaspar, 2015).

The Russian food import ban of 2014 caused negative short-run effects on the domestic Russian market as well, especially considering that imports could not be substituted with domestic production in the short-term period. Boulanger et al. (2016) estimated the short-run impact of the Russian food import ban on Russia's domestic market. Their results indicate losses of 3.4 billion EUR from the economy due to the ban. In contrast to the negative short-run effects, some studies indicate that the food import ban had some positive effects in the long run, such as reduced import dependency from Russia, achieving self-sufficiency targets in certain sectors and improving competitiveness of Russia's agricultural trade (Smutka et al., 2016, Liefert \& Liefert, 2015). Nevertheless, these positive effects were followed by significant side effects, such as increased domestic price volatility (as in the pork sector; see Götz \& Jaghdani, 2017; Djuric et al., 2015) and a decrease in product quality (e.g. cheese; see Tleubayev et al., 2018). Furthermore, Hinz and Monastyrenko (2016) estimate that an additional 3 million people in Russia dropped below the poverty line between 2014 and 2015, mainly due to short- and mid-term domestic retail price increases of the banned products.

Besides analysing the effects of the import ban, there are no studies looking at further production and trade developments of the Russian agricultural sector once the import ban is lifted. There are only two studies that look into potentially stronger free trade agreements between Russia and the EU. Van Berkum et al. (2016) analyse two different scenarios: a reduction of tariffs (a "deeper integration" scenario) and nontariff barrier costs (a "liberalisation" scenario) between Russia and the EU. Their results indicate that Russian agri-food production would benefit from both scenarios, while there would be negligible effects on the EU agri-food sector. On the other hand, Felbermayr et al. (2016) investigate a broader economic perspective of EU and EAEU trade liberalisation, arguing that trade liberalisation between the EU and EAEU (i.e. from Lisbon to Vladivostok) would be a win-win situation for both parties. They estimate that the EU would increase its total exports to the EAEU by about $60 \%$ (with the agriculture and automotive industries being leading sectors), while German exports alone would increase by $2 \%$ (i.e. about 19 billion USD). In contrast, Felbermayr et al. (2016) argue that the Eastern European countries, especially Russia, would benefit even more than the EU and that the free trade area would increase Russian exports by about $32 \%$ compared to the base year of 2011 .

\section{METHODOLOGY AND DATA}

In order to assess the future developments of Russian agricultural production and trade and the resulting competitiveness of the European and German market participants in the Russian market, we use the general equilibrium model MAGNET (Woltjer et al., 2014).

The application of MAGNET is appropriate as it depicts bilateral trade relations between regions, as well as domestic agricultural policy measures in the form of subsidies or taxes per sector. For the analysis, the data on Russian agricultural supports was updated and supplemented. Since the official data from the Russian Ministry of Agriculture on national and regional agricultural policies, and for production subsidies in particular, was insufficient, data from the OECD's Producer Support Estimate (2017) was used. Thus, both bilateral trade policies and support for Russia's domestic agricultural sector, which has increased significantly following the introduction of the food import ban, were investigated by this research. The MAGNET model is best suited for both policy changes compared to other models (e.g. AGMEMOD, CAPRI, FARMIS, etc.), as it reflects both bilateral trade and the effects of political support on different market actors (producers, processing industries, government and consumers). The MAGNET model is a 
global, dynamically recursive and general equilibrium model that encompasses the entire economy (Woltjer et al., 2014).

MAGNET is based on the GTAP database version 9 (Aguiar et al., 2016), which contains 140 countries or regions and 57 sectors, and has been extended and refined over time (Woltjer et al., 2014). The database is described in the form of a Social Accounting Matrix (SAM). In the SAM, all economic and financial transactions are monetised between sectors, regions and market participants (producers, processing sectors, private and public households). The SAM describes the complete economy for the 2011 year in the form of value data for production; bilateral trade; consumption; existing production factors (i.e. labour, capital, land and natural resources); costs for upstream products in different sectors (e.g. the cost of meat production for the input live animals); and taxes. For this particular research, MAGNET's database has been aggregated into 41 countries or regions and 39 products. On this basis, projections were simulated until 2030. These projections are driven by macroeconomic assumptions (development of economic growth and population), policies (such as import bans, tariffs, subsidies and taxes) and technological changes. Due to changing macroeconomic assumptions and technical progress over time, the model is dynamic. Scenarios are defined in MAGNET by varying these assumptions.

This study investigates the economic effects of the abolition of the Russian import ban on agricultural products and food and the creation of a free trade area between the EU and EAEU (Lisbon-Vladivostok initiative) within four model scenarios. The scenarios build upon each other by moving from a situation with a Russian food import ban and high agricultural support to a free trade agreement between the EU and EAEU and lower agricultural support (Figure 1). As mentioned before, the main limitations of the free trade agreement scenarios between the EU and the EAEU are indicated by the current geo-political ${ }^{2}$ and economic relations, especially between Russia and the EU (Davis, 2014).

The reference scenario (REFERENCE) assumes a continuation of the food import ban imposed in 2014 (Figure 1). The market policies in Russia represented in the model have been adjusted until 2016 based on data on domestic support for agricultural products in Russia published in the OECD Producer Support Estimate and remained unchanged for the rest of the calculations until 2030.

In the no import ban scenario (NOBAN), the Russian food import ban is abolished in 2020 and domestic agricultural support in Russia will remain at the high level as implemented in the reference scenario (Figure 1).

The third scenario, free trade agreement and high domestic support (FTA_HIGHSUPPORT), builds upon the NOBAN scenario, i.e., the ban is lifted in 2020. Additionally, a free trade area between the EU and EAEU is established and high domestic support in Russia is maintained from 2023 onwards (Figure 1).

In the fourth scenario, free trade agreement and reduced domestic support (FTA_LOWSUPPORT), a free trade area between the EU and EAEU is established and domestic support in Russia is reduced by 50\% (Figure 1). Hence, this scenario is the same as the FTA_HIGHSUPPORT scenario except that the Russian domestic agricultural support is reduced from 2023 onwards.

\footnotetext{
${ }^{2}$ The main factors underling current political relations between the EU and Russia are out of the scope of this paper.
} 


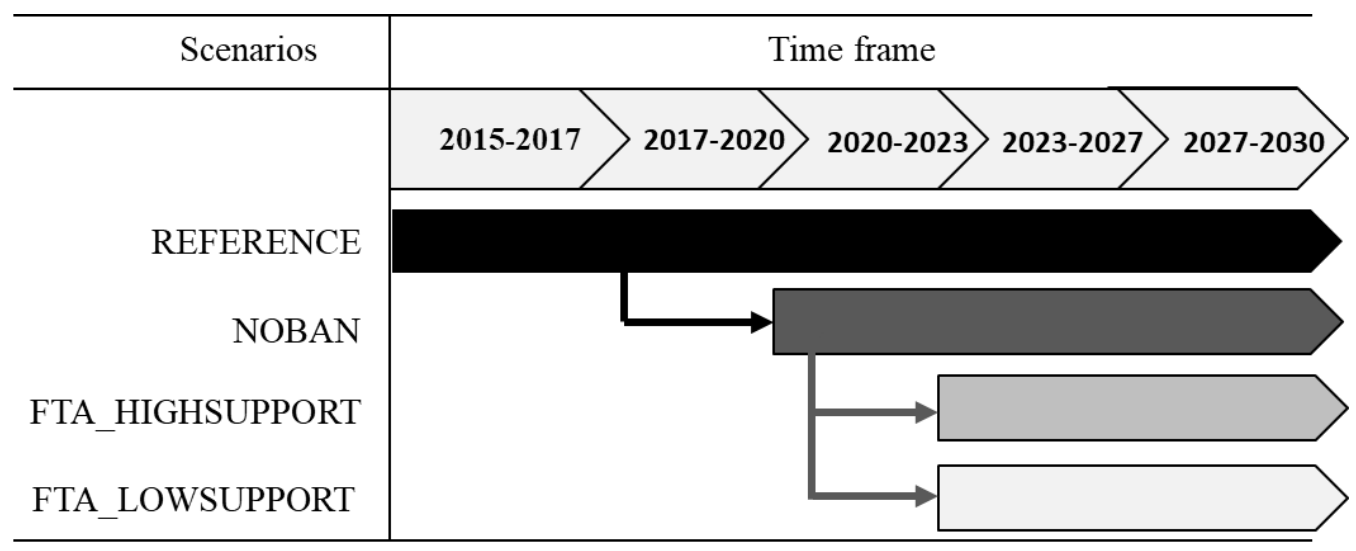

Figure 1. Model scenarios

Note: Scenarios are described in the text.

Source: Authors' illustration.

\section{EMPIRICAL RESULTS}

Modelling results for the reference scenario (REFERENCE) indicate that agricultural production in Russia increases by 16\% from 2015 to 2030 followed by an increase in agricultural and food imports from 'non-banned' countries by $18 \%$ if the food import ban is still in place. In the meat sector, production increases by more than $18 \%$ and imports by more than $24 \%$, whereas the production of dairy products is slightly reduced $(-0.8 \%)$, but imports increase by $23 \%$. In comparison, the production of agricultural goods in other regions increases relatively more (worldwide $+30 \%$, Europe $+20 \%$ ).

By eliminating the food import ban (NOBAN scenario), Russian production of agricultural products that were affected by the ban slightly decrease after the ban is removed. In contrast, the production of agricultural goods not previously affected by the ban slightly increases (+1.07\%) until 2030 (Figure 2). The main arguments for this are that Russian domestic producers will face strong competition from agricultural products of higher quality, especially for the previously banned products, i.e. meat and dairy, for which our results indicate a decrease in production by $3 \%$ on average. Concerning the meat sector, cattle production records a stronger decrease of $4 \%$ compared to a $2.3 \%$ decrease in pork and poultry production. These results are in line with the fact that Russian producers are more specialised in pork and poultry production compared to cattle. On the other hand, Russia will have a competitive advantage producing those products that were not under the ban, e.g. wheat, other cereals and oilseeds (mainly sunflower). Furthermore, trade with the EU is estimated to increase again and even surpass the trade volumes of 2011 in 2030. Internationally, the effects of the Russian removal of the food import ban are hardly noticed. Our results also indicate a slight decline in the production of agricultural products in the EU28 and Germany, which were previously affected by the Russian food import ban (Figure 2). The reason for this somewhat unexpected market reaction might be the fact that the Russian import ban relates not only to imports of selected agricultural products from the EU, but also to those from the USA, Canada, Australia and Norway. With the abolition of the food import ban, the Russian import tariffs will be fixed at the levels that were applied before the import ban was established. Accordingly, the formerly boycotted countries are affected in different ways by these different duty rates. In EU countries, the removal of the food import ban does not result in a resurgence of the old level of trade, and domestic production effects are correspondingly low.

A creation of the hypothetical free trade area between the EU and EAEU (FTA_HIGHSUPPORT scenario), which sets all tariffs at zero, leads to further intensified trade between the two regions. In Russia, these trade developments result in a further increase in agricultural production that was previously not 
affected by the food import ban (e.g. arable crops). In contrast, the production of dairy and meat products further decline by about 7\% on average until 2030 (Figure 2). On the other hand, our results indicate a particularly strong increase in the production of beef in the EU and Germany by $4.3 \%$ and $26 \%$, respectively.

With reduced agricultural support in Russia under the free trade area between the EU and EAEU (FTA_LOWSUPPORT scenario), the results change only slightly compared to the FTA_HIGHSUPPORT scenario (Figure 2). This indicates the effectiveness of the current import substitution policy by the Russian government, and also corresponds with the scientific evidence showing that an influence of agricultural subsidies on production efficiency is not confirmed for Russia (Bobojonov et al., 2016).

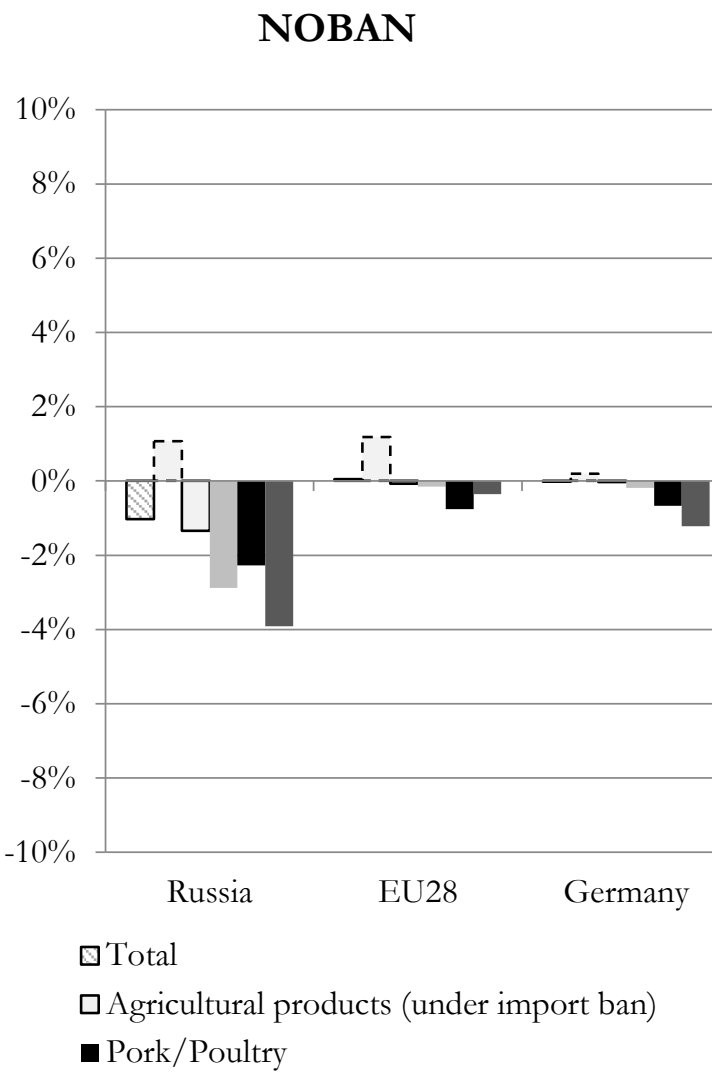

FTA_HIGHSUPPORT

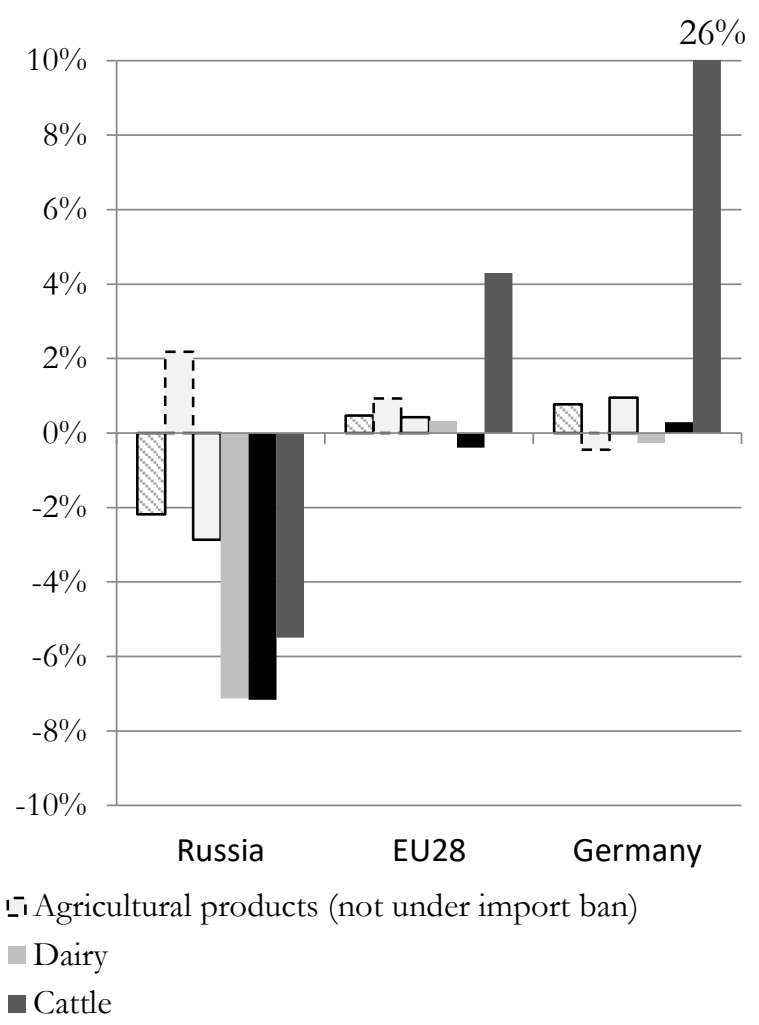

Figure 2. Agricultural production changes in Russia, Europe and Germany in 2030 compared to the reference scenario, in percent

Source: Authors' calculations based on the MAGNET model.

\section{CONCLUSIONS}

In this paper, we have assessed possible future developments of the agricultural sector in Russia and the EU. We have considered different scenarios ranging from the continuation of the food import ban under current geopolitical conditions to a highly hypothetical scenario of a common economic space from Lisbon to Vladivostok with free agricultural trade between the EU and the EAEU.

Our results from the global and dynamically recursive, general equilibrium MAGNET model indicate that, given that the import tariffs stay as they were before 2014, the removal of the food import ban will 
cause only a slight decrease in Russia's total agricultural production. Agricultural products that were previously protected by the ban will again be confronted with competitive products (especially cattle production) of a higher quality (especially dairy products). Nevertheless, due to high import tariffs and imports being quantitatively limited by quotas (similar to levels before 2014), imports will not increase significantly. In contrast, for products that were not under the ban (e.g. wheat, other cereals and oilseeds), Russia will maintain its competitive advantage in production and will continue further exports of these products once the food import ban is removed. Furthermore, an abolishment of trade barriers with the EU, under the hypothetical scenario of a Lisbon-Vladivostok free trade area, will further contribute to an increase in production of these products in Russia.

Since the EU and Germany were one of the most important trading partners with Russia before 2014, the removal of the Russian food import ban would not cause any significant impacts on domestic agricultural production. Our results further indicate that if a free trade area between the EU and the EAEU is created, the consequences for the Russian agricultural sector will be much higher compared to the EU. Our results indicate a near 7\% decrease in dairy production and an almost $6 \%$ decrease in meat production in Russia, on average. In contrast, we observe an increase in cattle production of $4 \%$ in the EU.

Overall, the removal of the Russian food import ban will not cause significant changes in the agricultural sectors of both Russia and the EU. EU-Russia agricultural trade will greatly depend on whether Russia continues with its import substitution policy or removes the trade barriers to certain extend after the food import ban is removed.

However, removing all trade barriers and creating a large free-trade area between the EU and EAEU will bring about some significant changes in the agricultural sectors of both sides. According to our results, EU farmers will benefit to a higher extent compared to Russian farmers. Nevertheless, it is difficult to say whether or not Russian farmers will become more competitive in the years following the creation of such a free-trade area. The increase in competitiveness will greatly depend on whether Russian farmers adopt adequate knowledge and modern technologies, as well as macroeconomic developments, especially the Rouble exchange rate, in the country.

\section{REFERENCES}

Aalto, P., \& Forsberg, T. (2016). The structuration of Russia's geo-economy under economic sanctions. Asia Europe Journal, 14, 221-237.

Aguiar, A., Narayanan, B., \& McDougall, R. (2016). An Overview of the GTAP 9 Data Base. Journal of Global Economic Analysis, 1.

BMEL (2014). Bericht über die Auswirkungen des russischen Importstopps auf die EU-Märkte für landwirtschaftliche Erzeugnisse und Lebensmittel http://www.bmel.de/SharedDocs/Downloads/ Ministerium/InternationaleZusammenarbeit/AuswirkungenRU.pdf?_blob=publicationFile

Bobojonov, I., Götz, L., Petrick, M., Hockmann, H., \& Glauben, T. (2016). Productivity effect or recent macroeconomic changes in Russia. Selected Paper, Samarkand Conference "Regional and International Cooperation in Central Asia and South Caucasus: Recent Developments in Agricultural Trade", November 2 4, Samarkand, Uzbekistan.

Boulanger, P., Dudu, H., Ferrari, E., \& Philippidis, G. (2016). Russian Roulette at the Trade Table: A specific Factors CGE Analysis of an Agri-food Import Ban. Journal of Agricultural Economics, 67 (2), 272-291.

Davis, I. (2014). NATO, the EU, Ukraine, Russia and Crimea: The "Rest" that was Never "Rest". NATO Watch Briefing Paper No. 49, April 3, 2014. www.natowatch.org

Dillen, K. (2015). The Russian ban on EU agricultural imports: A bilateral extension of AGLINK-COSIMO. Paper presented at the International Conference of Agricultural Economists: "Agriculture in an interconnected world", Milan, Italy, 8-14 August 2015. 
Djuric, I., Götz, L., \& Glauben, T. (2015). Trade diversion and high food prices - The impact of the Russian pig meat import ban. In International Agricultural Trade Research Consortium, Trade and Societal Well-Being, December 13-15, 2015, Clearwater Beach, Florida. Clearwater Beach, Florida, USA: Agricultural and Applied Economics Association \& Western Agricultural Economics Association.

EastContact (2017). The Future of European and Eurasian partnership: Rebuilding trust. Defining drivers. Overcoming barriers. East Forum Berlin, 2017.

European Parliament (2017). Russia's and the EU's sanctions: economic and trade effects, compliance and the way forward. Directorate-General for external policies.

Fedoseeva, S. (2016). Russian agricultural import ban: Quantifying losses of German agri-food exporters. Paper presented at the 56th annual conference of the German Association of Agricultural Economists (GEWISOLA):"Agricultural and Food Economy: Regionally Connected and Globally Successful", Bon, Germany, 28-30 September 2016.

Felbermayr, G., Aichele, R., \& Gröschl, J. (2016). Free Trade from Lisbon to Vladivostok: Who Gains, Who Loses from a Eurasian Trade Agreement. Study for the Bertelsmann Foundation.

Freytag, J. (2018). A New Movement for a Common Economic Space. EastContact, 50-53.

Giumelli, F. (2017). The Retributive Impact of Restrictive Measures on EU Members: Winners and Losers from Imposing Sanctions on Russia. Journal of Common Market Studies, 55 (5), 1062-1080.

Götz, L., \& Djuric, I. (2016). Russia wants to become the largest agricultural exporter (Russland will größter Agrarexporteur werden). BWagrar.

Götz, L., \& Jaghdani, J.T. (2017). Russia's agricultural import substitution policy: Price volatility effects on the pork supply chain. Paper presented at the 57th Annual Conference of the German Association of Agricultural Economists (GEWISOLA), September 13-15, 2017, München, Germany.

Hinz, J., \& Monastyrenko, E. (2016). Bearing the cost of politics: Consumer prices in Russia. The European Trade Study Group (ETSG) working paper, no 318.

Judit, S., \& Nikulin, E.E. (2017). The economic effect of Russia imposing a food embargo on the European Union with Hungary as an example. Studies in Agricultural Economics, 119, 85-90.

Kaspar, O. (2015). No milk for the bear: the impact on the Baltic states of Russia's counter-sanctions. Baltic Journal of Economics, 15 (1), 38-49.

Kutlina-Dimitrova, Z. (2015). The economic impact of the Russian import ban: a CGE analysis. European Commission - Chief Economist Note, Issue 3, December 2015.

Liefert, W. M., \& Liefert, O. (2015). Russia's Economic Crisis and its Agricultural and Food Economy. Choices - The magazine on food, farm, and resource issues, Agricultural and Applied Economics Association, 30 (1).

Mauricas, Z. (2015). The effect of Russian economic sanctions on Baltic States. Overview of the Nordea Bank AB. https://nexus.nordea.com/research/attachment/17231

Mo, Y. (2016). Assessment of Russian Embargo impact on economies of the EU countries - An input-output approach. Master thesis, Swedish University of Agricultural Sciences, Department of Economics.

Nelson, R.M. (2017). U.S. Sanctions and Russia's Economy. CRS Report prepared for Members and Committees of Congress, Congressional Research Service, 7-5700, R43895, February 17, 2017.

OECD (2017). Producer Support Estimate: Russia http://www.oecd.org/tad/agriculturalpolicies/producerandconsumersupportestimatesdatabase.htm. Abgerufen am: 04.10.2017

Prikhodko, D., \& Davleyev, A. (2014). Russian Federation: Meat sector review. Rome, Italy.

Sagi, J., \& Nikulin, E. E. (2017). The economic effect of Russia imposing a food embargo on the European Union with Hungary as an example. Studies in Agricultural Economics, 119, pp. 85-90.

Smutka, L., Spicka, J., Ishchukova, N., \& Selby, R. (2016). Agrarian import ban and its impact on the Russian and European Union agrarian trade performance. Agricultural Economics - Czech, 62, 493-506.

Süddeutsche Zeitung (2010). Von Lissabon bis Wladiwostok. Süddeutsche Zeitung - Führungstreffen Wirtschaft 2010, November 25, 2010. Interview available at http://www.sueddeutsche.de/wirtschaft/putin-plaedoyer-fuerwirtschaftsgemeinschaft-von-lissabon-bis-wladiwostok-1.1027908 
Tleubayev, A., Jaghdani, J.T., Götz, L., Svanidze, M. (2018). The effects of trade policy on domestic dairy market: the case of Russian food import ban on regional cheese market integration in Russia. Paper presented at the 30th International Conference of Agricultural Economists (ICAE), Vancouver, Canada.

Tyll, L., Pernica, K., \& Arltová, M. (2018). The impact of economic sanctions on Russian economy and the RUB/USD exchange rate. Journal of International Studies, 11(1), 21-33. doi:10.14254/2071-8330.2018/11-1/2

UN COMTRADE (2017). International Trade Statistics Database. United Nations Comtrade database, www.comtrade.un.org

van Acoleyen, M. (2015). The Impact of Sanctions on Trade: An Application to the European-Russian Case. From the SelectedWorks of Research in Economics. Faculty of Economics and business, Leuven.

van Berkum, S. (2014). EU agricultural trade relations with Eastern Neighbours: current state and future perspectives in a changing policy framework. AGRICISTRADE project working paper. LEI Wageningen University, 1.9.2014.

van Berkum, S., Banse, M., Deppermann, A., Erjevec, E., Djuric, I., Philippides, G., \& Wolf, V. (2016). Exploring the potential for agriculture and trade in CIS. Synthesis of findings of the EU FP7 financed AGRICISTRADE project. www.agricistrade.eu

Veebel, V., \& Markus, R. (2018). The bust, the boom and the sanctions in trade relations with Russia. Journal of International Studies, 11(1), 9-20.

Vitunskiene, V., \& Serva, E. (2017). Lithuanian Agri-food Industry Responses to Russian Import Ban on Agricultural Products. Institute of Economic Research Working Papers, No. 136/2017, Poland.

Woltjer, G., Kuiper, M., Kavallari, A., van Meijl, H., Powell, J., Rutten, M., Shutes, L., \& Tabeau, A. (2014). The MAGNET model - module description, LEI Report, LEI Wageningen UR (University \& Research center), The Hague. $\quad$ http://www.wur.nl/en/Publication-details.htm?publicationId=publication-way-343535383037. Accessed at: 09.02.2017.

Yatsenko, O., Nitsenko, V., Karasova, N., James, H.S.Jr., \& Parcell, J.L. (2017). Realization of the potential of the Ukraine-EU free trade area in agriculture. Journal of International Studies, 10(2), 258-277. doi: 10.14254/20718330.2017/10-2/18 